IZA DP No. 4488

The Institutional Context of an "Empirical Law":

The Wage Curve under Different Regimes of

Collective Bargaining

Uwe Blien

Wolfgang Dauth

Thorsten Schank

Claus Schnabel

October 2009 


\title{
The Institutional Context of an "Empirical Law": The Wage Curve under Different Regimes of Collective Bargaining
}

\author{
Uwe Blien \\ Institute for Employment Research (IAB), \\ University of Bamberg and IZA \\ Wolfgang Dauth \\ University of Erlangen-Nuremberg and IAB \\ Thorsten Schank \\ University of Erlangen-Nuremberg \\ Claus Schnabel \\ University of Erlangen-Nuremberg and IZA
}

\section{Discussion Paper No. 4488 \\ October 2009}

\author{
IZA \\ P.O. Box 7240 \\ 53072 Bonn \\ Germany \\ Phone: +49-228-3894-0 \\ Fax: +49-228-3894-180 \\ E-mail: iza@iza.org
}

Any opinions expressed here are those of the author(s) and not those of IZA. Research published in this series may include views on policy, but the institute itself takes no institutional policy positions.

The Institute for the Study of Labor (IZA) in Bonn is a local and virtual international research center and a place of communication between science, politics and business. IZA is an independent nonprofit organization supported by Deutsche Post Foundation. The center is associated with the University of Bonn and offers a stimulating research environment through its international network, workshops and conferences, data service, project support, research visits and doctoral program. IZA engages in (i) original and internationally competitive research in all fields of labor economics, (ii) development of policy concepts, and (iii) dissemination of research results and concepts to the interested public.

IZA Discussion Papers often represent preliminary work and are circulated to encourage discussion. Citation of such a paper should account for its provisional character. A revised version may be available directly from the author. 


\section{ABSTRACT \\ The Institutional Context of an "Empirical Law": The Wage Curve under Different Regimes of Collective Bargaining*}

The wage curve identified by Blanchflower and Oswald (1994) postulates that the wage level is a decreasing function of the regional unemployment rate. In testing this hypothesis, most empirical studies have not taken into account that differences in the institutional framework may have an impact on the existence (or the slope) of a wage curve. Using a large-scale linked employer-employee data set for western Germany, this paper provides a first test of the relevance of different bargaining regimes and of works councils for the existence of a wage curve. In pooled regressions for the period 1998 to 2006 as well as in worker-level or plant-level fixed-effects estimations we obtain evidence for a wage curve for plants with a collective bargaining agreement at firm level. The point estimates for this group of plants are close to the -0.1 elasticity of wages with respect to unemployment postulated by Blanchflower and Oswald. In this regime, we also find that works councils dampen the adjustment of wages to the regional unemployment situation. In the other regimes of plants that either do not make use of collective contracts or apply sectoral agreements, we do not find a wage curve.

JEL Classification: $\quad J 50$

Keywords: $\quad$ wages, wage curve, collective bargaining, Germany

Corresponding author:

Claus Schnabel

Friedrich-Alexander-Universität Erlangen-Nürnberg

Lehrstuhl für Arbeitsmarkt- und Regionalpolitik

Lange Gasse 20

90403 Nürnberg

Germany

E-mail: claus.schnabel@wiso.uni-erlangen.de

\footnotetext{
* The authors would like to thank the IAB Research Department "Establishments and Employment" as well as the Research Data Centre of the Federal Employment Agency for excellent support with the data, and participants in the 2009 ERSA Congress in Lodz for helpful comments.
} 


\section{MOtIVATION}

Following the seminal study by Blanchflower and Oswald (1994), a large number of empirical studies have tested the existence of a wage curve, which postulates that the wage level is a decreasing convex function of the regional unemployment rate. However, extant studies usually have not taken into account institutional details of the wage determination process. Therefore, the specific contribution of our paper is that for the first time we make use of a linked employer-employee data set with information on industrial relations and collective bargaining regimes in estimating wage curves for western Germany and are able to relate the wage elasticities obtained to these different regimes. Since there is considerable variation of institutional arrangements in Germany, it is also possible to draw comparisons to results for other countries (e.g. to the wage curve in the UK) that may reflect specific institutional settings. At the same time, the institutional variation provides an opportunity to assess the relative importance of efficiency wage and wage bargaining explanations of the wage curve.

Blanchflower and Oswald (1994) argue that low unemployment rates reduce employees' risk of being laid off or alternatively increase their chances of finding another job in the case of having been fired. This strengthens employees' bargaining position and increases their incentives to reduce their working effort. Therefore, according to bargaining or efficiency wage theories, respectively, companies in regions with lower unemployment rates might be induced to pay higher wages, ceteris paribus. In their empirical analyses for a number of countries (including Britain, Canada and the US), Blanchflower and Oswald (1994, 2005) found that the elasticity of wages with respect to unemployment was -0.1 . The effect was so stable that the authors dared to call it an "empirical law of economics".

The wage curve in Germany has been analyzed several times, pioneering studies were Wagner (1994) and Blanchflower and Oswald (1994, 1996). Using an especially rich data set with a long time horizon Baltagi, Blien and Wolf (2009) confirmed that in western Germany the wage elasticity of regional unemployment is lower in absolute terms (-0.03) than formulated in Blanchflower and Oswald's empirical law (see also Büttner 1999). It is an open question, however, why this is the case. The answer may be related to the fact that - due to the lack of data most empirical studies on the wage curve have not been able to explicitly take into account the large differences in industrial relations and wage bargaining institutions which may have an impact on the actual slope of the wage curve. Binding sectoral collective wage agreements, for example, could hinder companies adapting their wages to regional conditions. In this case, a (regional) wage curve would not exist or (if it did) it was very flat. In contrast, wage setting at company level (which can be 
influenced directly by unions and indirectly by works councils) should be more responsive to regional unemployment.

In testing the relevance of different bargaining regimes and labour market institutions (such as works councils) for the wage curve, the paper proceeds as follows: Section 2 briefly explains the institutional background of wage setting in Germany, identifying four collective bargaining regimes. Hypotheses on the potential wage-unemployment relationships in these regimes are derived in section 3. The linked employer-employee data used in our empirical analysis are described in section 4. Section 5 presents our empirical results, and section 6 concludes.

\section{INSTITUTIONAL BACKGROUND}

The German system of industrial relations is characterized by a dual representation of workers through trade unions and works councils, encompassing employee and employer organizations, and a system of predominantly sectoral-level collective bargaining (for details, see Keller 2004). The constitutionally protected principle of bargaining autonomy gives organizations of employers and employees the right to regulate wages and working conditions without state interference. Collective agreements are legally binding and may be concluded either as multi-employer agreements at sectoral level or as single-employer agreements at firm level. Unlike the situation in the UK or the US, collective bargaining in Germany is still mainly conducted at the sectoral level. ${ }^{1}$ While sectoral negotiations mostly take place in regional bargaining districts, the regional negotiations within one sector are closely coordinated by the officials of the appropriate sectoral trade union and employers association, so that variations between them are small. Collectively agreed norms are minimum terms which means that companies bound by (sectoral- or firm-level) collective agreements cannot undercut, only improve upon these terms and conditions, through voluntary premiums such as higher wages or more holidays. The actual implementation and monitoring of sectoral-level collective agreements is increasingly relegated to company management and works councils.

According to the German Works Constitution Act, works councils are mandatory but not automatic in all establishments exceeding a size threshold of five permanent employees. They are not automatic in that they must be elected (by the entire workforce in the establishment). While works councils are formally independent of unions, in practice the majority of works councilors are union members. The size of

For a comparison and analysis of collective bargaining structures in Germany and Britain, see Schnabel, Zagelmeyer and Kohaut (2006). 
the works council is fixed by law and is a function of the establishment's employment level (for more institutional details, see Addison, Schnabel and Wagner 2001). Works councils have fairly extensive rights of information and consultation prescribed by law. In addition, they also have co-determination rights on "social matters" such as remuneration arrangements, the regulation of overtime and working hours, and health and safety measures. In contrast to unions, works councils may not call a strike, and they are excluded from reaching agreement with the employer on wages and working conditions that are settled or normally settled by collective agreements between unions and employer associations at sectoral level (unless the latter explicitly authorize works agreements of this sort). However, their rights of information, consultation and co-determination on many other issues mean that works councils have bargaining power which can be used for rentseeking, and effective wages have been shown to be higher in establishments with works councils (e.g. Addison, Schnabel and Wagner 2001, Hübler and Jirjahn 2003).

The institutional framework sketched above implies that there exist three main bargaining regimes in Germany, one of which can be sub-divided further: Firms may either not make use of collective bargaining, they may conduct bargaining at firm level or they may apply collective agreements negotiated at sectoral level. In the latter case, they may either exactly stick to these agreements or they are free to voluntarily pay wages above the agreed scale. In our subsequent econometric analysis of the wage curve, we will make use of these four bargaining regimes.

(Table 1 about here)

The presence of these four regimes and the coverage of collective agreements in western Germany are shown in Table 1 based on information from the representative IAB Establishment Panel described below. It can be seen that in 2006, the final year of our investigation, sectoral-level collective agreements applied in about 43 percent of private-sector plants with five or more employees, covering 56 percent of workers. Almost half of plants in this group (or 20 percent of all plants) paid actual wages above the scale agreed in sectoral contracts. Single-employer collective agreements at firm level were found in just 3 percent of establishments, employing about 8.5 percent of workers. Almost 54 percent of plants and about 35 percent of employees were not covered by a collective agreement, which means that their wages and working conditions were laid down in individual contracts. Table 1 also provides some information about the presence of works councils in each regime. It can be seen that works councils exist in only about 4 percent of 
plants without collective agreements whereas 44 percent of plants with firm-level agreements do also have a works council. This probably reflects a size effect since plants without a collective agreement are usually smaller whereas works councils are more often found in large companies where their legal powers are much stronger. ${ }^{2}$

\section{HyPOTHESES ON THE EXISTENCE OF A WAGE CURVE}

While Blanchflower and Oswald (1994) discuss a number of theoretical approaches, there are two main theories explaining the existence of a wage curve (which however have been indistinguishable empirically up to now): The wage curve could be generated by plants paying efficiency wages or by the bargaining process between employers and employees. According to the efficiency wage approach, firms are motivated by their own interest to pay higher wages in the case of lower unemployment. Relatively high wages and high rates of unemployment are substitutes for the firm to secure high levels of worker effort and of employment stability. Since the level of unemployment is outside the reach of individual firms they are inclined to increase wages until the intended level of effort is secured. Workers are motivated to work hard either by a wage premium or by the threat of dismissal. If the unemployment rate is high, workers who lose their jobs will have difficulties in finding another job and obtain only relatively low unemployment benefits, so that firms are able to pay lower wages. Blanchflower and Oswald (1994) use a modification of the famous Shapiro and Stiglitz (1984) efficiency wage model to develop the wage curve. Alternatively efficiency wages could be derived from Akerlof's (1982) model of gift exchange, which has been applied successfully in laboratory tests of experimental economists (Fehr, Kirchsteiger and Riedl 1998)

In the alternative wage negotiation approach the assumed situation is different. Here, firms try to keep wages down but are forced to increase the level of payment in the case of low unemployment rates, since then workers have favourable outside options and are able to be 'tough' negotiators. This applies to the situation of collective bargaining as well as to individual wage negotiations. If unemployment is relatively high, however, workers are deterred by the possibility of being without a job and without a regular labour income, and their bargaining position is weakened. To formalize the process and the consequences of negotiations, Blanchflower, Oswald and Sanfey (1996) use a theoretical model of bargaining which allows a

2 The determinants of works council existence are investigated, inter alia, by Addison et al. (2003) and Jirjahn (2009), whereas the determinants of collective bargaining structure are studied by Hübler and Jirjahn (2003), Kohaut and Schnabel (2003) and Schnabel, Zagelmeyer and Kohaut (2006). 
simple and elegant exposition. It is assumed that firms produce positive profits which are divided between workers and firm-owners. Wages are negotiated between both parties, whereas the employment level is fixed by the firm-owners only. The Nash-solution for the wage level is influenced by the regional unemployment rate which defines the outside option of workers.

Theoretically, the wage curve can be interpreted as an alternative for the labour supply function commonly found in a more standard labour market model. Blanchflower and Oswald (1994) apply the so-called "wage setting curve" of mainstream macro models developed by Layard, Nickell and Jackman (1991, 2005) and others (see also Carlin and Soskice 2006) to regional labour markets. In the regional setting the basic theory is parallel to the national case, with the exception that with regional economies the complications of inflation can be ignored. The incorporation of the regional dimension in the analysis of wages has the advantage of providing empirical researchers with variation, since they are able to study many small (regional) economies instead of only a single large one, while still holding constant the institutional framework.

In our analysis, we go one step further and take regional as well as institutional variations into account. Against the institutional background and the theoretical considerations sketched above, we can derive four hypotheses concerning the existence of a wage curve in Germany:

1) A wage curve should show up in the sub-sample of plants not bound by collective agreements since wage adjustments to changing (regional) economic conditions and unemployment may be easiest in individual wage contracts. In this case, the wage curve might predominantly reflect efficiency wage considerations by employers (although effects from bargaining between individual employees and employers cannot be fully ruled out).

2) A wage curve should also be found in the sub-sample of plants that make use of firm-level bargaining since here wages can be adjusted to the specific situation of the plant, taking account of the regional labour market situation. Here the bargaining explanation of the wage curve may be more relevant (although higher wages pushed through by unions could coincide with efficiency wage considerations of the employer).

3) No wage curve should be found in the sub-sample of plants that exactly apply sectoral collective agreements since these agreements do not take into account regional or plant-specific factors.

4) A weak wage curve relationship may show up in the fourth sub-sample of plants which are also bound by sectoral agreements but pay higher wages than stipulated 
in those agreements. Here low regional unemployment may have induced employers to pay higher wages (either due to efficiency wage considerations or due to higher worker bargaining power). However, since wages may not be lowered in cases of high regional unemployment due to the binding minimum character of sectoral agreements, any observed wage curve relationship might be weaker.

\section{DATA}

The following analysis uses data from the Linked-Employer-Employee-Dataset (LIAB) of the Institute for Employment Research (IAB) at the German Federal Employment Agency (see Alda, Bender and Gartner 2005 for a more detailed description). This data base actually consists of two separate data sets which are linked through a plant identifier available in both data sets. The employer side is given by the IAB Establishment Panel, a stratified random sample of up to 10.105 establishments (not firms) per year in western Germany. Since this panel has a strong focus on employment-related topics, questions deal, among other things, with the number of employees, working time, profitability, the establishment's commitment to collective agreements and the existence of a works council. This survey data is merged to administrative data of the establishments' employees. This is possible since German law requires all employers to report certain information such as wages paid and formal qualification about every employee who is subject to obligatory social insurance. Wages are measured especially accurately since the respective variable directly reports the contributions to the social insurance system and the workers' claims on pensions after retirement. Merging the plant level data to the individual data of the establishments' employees results in a large panel data set that is a combination of survey and administrative data which are especially reliable with respect to the wage information. Apart from this, the data include highly differentiated information on individual workers and on individual plants which is needed to control for the heterogeneity of workers and workplaces.

It should be noted that the LIAB's first year of observation is 1993. However, due to unclear formulations in the IAB Establishment Panel's questionnaire, the information on wage agreements is not usable in the years 1993-1997. Hence, we only use observations of the years 1998-2006. We also restrict our sample to establishments that have at least five employees (when first appearing in the data set), since only in these establishments works councils may be elected. We further exclude establishments that are located in the eastern part of Germany since there are still huge disparities in the labour market situation and also institutional differences concerning bargaining regimes and works councils between western 
and eastern Germany, which is in a long transition period characterized by particularly high unemployment. ${ }^{3}$

To minimize distortion caused by varying working hours, we use only full-time employees in the age of 18 to 65 years. Furthermore, we have no information on overtime hours. Controlling for establishments' profit situation and the business cycle using dummy variables for each year of observation, we hope to overcome this drawback. Workers who earn less than 20 euro a day are excluded from the dataset. Since their wages are subject to a lump-sum social security contributions, there may be peculiar mechanisms of wage determination in this group which we are not able to disentangle. As wages in the public sector are determined at the national level and show little regional variation, we also eliminate public employees.

The wage variable is an individual's average daily wage. It is deflated by the consumer price index calculated by the Federal Statistical Office. This price index is based on the year 2005 and applies for Germany as a whole. Since the wage data has originally been taken for administrative purposes to calculate retirement pensions, it is highly reliable and not subject to problems such as refusal by respondents. However, one drawback of this data is that wages are censored above the contribution assessment ceiling of social security. For example in 2006, the threshold was 63,000 Euros per year in western Germany, which translates into a daily wage of 172.6 Euros. About 11 percent of wages in our sample are censored at this threshold. However, previous analyses and tests with crosssectional data show that imputation of wages would only lead to very small changes in Mincer-type models (see, for instance, Schank, Schnabel and Wagner 2007).

The regional units of observations are the 326 administrative districts (Landkreise und kreisfreie Städte - NUTS3 regions) in western Germany. These are the smallest regions for which labour market data is reported. We add local unemployment rates to our data set, which are retrieved from the administrative statistics of the Federal Employment Agency and are calculated by dividing the reported number of unemployed persons at the end of June of the year of observation by the sum of total unemployment and dependent civil employment.

Apart from the individual wage and the regional rate of unemployment, we use a large number of control variables in our wage regressions. These reflect individual characteristics of employees as well as characteristics of the corresponding establishments. This rich panel data set with 7,126,277 observations over the period $1998-2006$ is used to estimate a wage curve for each of the four different

3 Elhorst, Blien and Wolf (2007) provide an analysis of the wage curve in eastern Germany (19931999), but they do not take into account institutional factors of wage setting. 
bargaining regimes separately. In addition, the role of works councils is analyzed and the sensitivity of the estimated wage elasticities to different specifications of the fixed-effects panel data model is checked in various robustness tests.

\section{EMPIRICAL ANALYSIS}

A general framework for our econometric investigation is represented by the following worker-level wage equation:

$$
\ln w_{i t}=\ln u_{r(i, t) t} \beta_{u}+X_{i t} \gamma_{1}+Z_{j(i, t) t} \gamma_{2}+\alpha_{t}+\alpha_{r(i, t)}+\alpha_{i}+\alpha_{j(i, t)}+\varepsilon_{i t}
$$

There are $i=1, \ldots, N$ individuals, $j=1, \ldots, J$ plants, $r=1, \ldots, R$ regions and $t=1, \ldots$, $T$ time periods; $r(i, t)$ and $j(i, t)$ index the region respectively the plant in which worker $i$ is employed at time $t$. The dependent variable ( $\left.\ln w_{i t}\right)$ is the log of the wage of worker $i$ at time $t$. The main variable of interest $\left(\operatorname{In} u_{r(i, t) t}\right)$ is the log of the unemployment rate in region $r$ at time $t$, where the subscript $r(i, t) t$ indicates that at time $t$ all workers in region $r$ share the same value for the unemployment rate. $X_{i t}$ is a vector of individual characteristics which are typically included in the empirical literature on wages. These comprises the following dummy variables, all of which are available from the employment statistics: indicators for gender, non-German nationality (European Union/Switzerland/North America, other countries), age and tenure bands, occupational status of the employee (unskilled blue-collar worker, skilled blue-collar worker, master craftsman/foreman, white-collar worker) and categories for educational attainment.

$Z_{j(i, t) t}$ defines characteristics of the plant, including the following variables obtained from the IAB Establishment Panel: plant size categories, a works council dummy, dummies characterizing the profitability of the plant and the state of the applied technology, a dummy indicating that a plant belongs to a larger unit as well as 30 dummy variables for sector affiliation. $\alpha_{t}$ denotes a standard macro effect in time period $t ; \alpha_{r(i, t)}, \alpha_{i}$ and $\alpha_{j(i, t)}$ capture time-invariant unobserved heterogeneity of the region, the worker and the plant respectively. The remaining error component is represented by $\varepsilon_{i t}$. In order to allow this error component to be correlated for workers within one plant, we use robust standard errors adjusted for clustering at the plant level.

Since we want to investigate whether the existence and magnitude of the wage curve depends on the institutional context (see hypotheses 1-4), we carry out all regressions separately for the four different bargaining regimes discussed in section 2: (i) plants with a bargaining agreement at the sectoral level where actual wages do not exceed stipulated wages, (ii) plants with a bargaining agreement at the 
sectoral level where actual wages exceed stipulated wages, (iii) plants with a firm level agreement, (iv) plants with no collective agreement. ${ }^{4}$

We start our investigation with a pooled regression for each sub-sample which ignores the worker and plant unobserved heterogeneity terms, i.e. $\alpha_{i}$ and $\alpha_{j(i, t)}$ enter the error term. However, we include regional $\left(\alpha_{r(i, t)}\right)$ and yearly fixed effects $\left(\alpha_{t}\right)$ such that the parameter estimates are identified via within-regional variation (net of the aggregate macro effect) of the respective variable. ${ }^{5}$ This is the specification for estimates on the wage curve preferred by Blanchflower and Oswald. The results of these estimations are reported in Table 2. The included variables explain almost two thirds of the wage variation at the individual level. Most of the control variables are highly significant and of the expected sign. Without going into detail, it is reassuring to see that wages rise with human capital (captured by age, tenure, education and occupation) and that the well-established firm size effect on wages shows up. Moreover, the existence of a works council is associated with higher wages in each regime.

Turning to the coefficient estimates of the regional unemployment rate, hypothesis 2 is clearly confirmed, since we do find a wage curve for plants with a collective bargaining agreement at firm level. The estimate implies that for workers in this group of plants a 10 percent increase in the regional unemployment rate lowers the individual wage by 12 percent. Moreover, the obtained parameter is very close and statistically not significantly different from -0.1 , the "empirical law" found by Blanchflower and Oswald (1994). The parameter estimates for the three other bargaining regimes are statistically insignificant and literally zero, so that we do not find any evidence for a wage curve for these types of wage agreement. This is in accordance with hypothesis 3 where we expected no wage curve for plants exactly applying sectoral collective agreements. The absence of a wage curve is also not very surprising for plants paying higher than stipulated wages where we expected at most a weak relationship (hypothesis 4). What is surprising, however, and is at odds with hypothesis 1 , is that no wage curve shows up for plants without any collective agreement.

In the next step, we examine whether our findings change when we control for individual- or plant-level heterogeneity. Therefore, we include $\alpha_{i}$ or $\alpha_{j(i, t)}$ in the

4 For this reason, the vector $Z$ does not include information on the type of wage agreement in the plant. Effectively, we fully interact all explanatory variables with the four different bargaining regimes. Plants which switch between bargaining regimes during the sample period enter different subgroups in different years.

5 To take the unemployment rate as an example, first the (weighted) average unemployment rate in a particular year is subtracted from each regional unemployment rate. Within-regional changes in this difference are needed to identify the parameter estimate on the regional unemployment rate. 
regressions and perform worker- respectively plant-level fixed-effects estimation. ${ }^{6}$ As can be seen from Table 3, our findings with respect to the wage curve remain unchanged. In fact, the point estimates for plants with a firm-level agreement are now even closer to the -0.1 elasticity of Blanchflower and Oswald (1994). ${ }^{7}$

Finally, we interact the log of the regional unemployment rate with the works council dummy to see whether the relationship between wages and unemployment depends on the existence of a works council. Although works councils are officially precluded from wage bargaining, their rights of information, consultation and codetermination on many other issues give them substantial bargaining power which could be used for pushing through higher wages and bonuses and for preventing wage cuts (see also Addison, Schnabel and Wagner 2001, Hübler and Jirjahn 2003). ${ }^{8}$ Table 4 shows that the wage curve for plants with a company level agreement is even stronger if a works council does not exist, with an elasticity of 0.236. If a works council exists, the added values of the unemployment coefficient and the interaction effect show that this elasticity is considerably lower, amounting to -0.119 . This suggests that works councils dampen the adjustment of wages to the regional unemployment situation, but it applies only in the sub-sample of plants with firm-level agreements. We still do not obtain any evidence in favour of a wage curve for the other three bargaining regimes, irrespective of whether or not a plant has a works council. ${ }^{9}$

6 Due to perfect multicollinearity between plants and regions (plants do not change their location in our regression sample) regional dummies drop out in the plant fixed-effects regressions.

7 We have not included worker and plant fixed effects at the same time. Because of movement between plants, there is no transformation which sweeps out both sets of fixed effects simultaneously, such that estimation becomes less straightforward. However, since only a small fraction of workers switches between plants in the sample, the two sets of fixed effects are highly collinear. Therefore, the estimates should not be flawed by ignoring one dimension of the heterogeneity. This is reassured by the finding that both fixed-effects estimations deliver very similar estimates.

8 For this specification, we have returned to the regression without worker or plant fixed effects. Had we included these, the identification of the parameters would rely on either plants introducing or abandoning a works council or a worker changing from a plant with a works council to an employer without (or vice versa). Since such changes are rare events (see Addison et al. 2003), the parameter estimates would be very imprecise.

9 Although at first glance Table 4 gives a different impression, tests of joint significance of the works council variable and the works council interaction term show that in these three regimes works councils still exert a significant positive influence on wages, which is consistent with the findings in Table 2. 


\section{CONCLUSIONS}

Using a large-scale linked employer-employee data set for western Germany, this paper has provided a first test of the relevance of different bargaining regimes and of works councils for the existence of a wage curve. In pooled regressions for the period 1998-2006 as well as in worker-level or plant-level fixed-effects estimations we obtained evidence for a wage curve for plants with a collective bargaining agreement at firm level. The point estimates for this group of plants are close to the -0.1 elasticity of wages with respect to unemployment postulated by Blanchflower and Oswald (1994) in their famous "empirical law of economics" on the wage curve. In the other regimes of plants that either do not make use of collective contracts or apply sectoral agreements, no wage curve was found.

Taking into account the respective institutional frameworks, our results correspond quite well to those obtained by Blanchflower and Oswald (1994) for Anglo-Saxon countries such as Britain and the US where bargaining predominantly takes place at firm level. When wages are negotiated at firm level, the regional labour market situation obviously is taken into consideration. In the German case, in addition to (sectoral) trade unions bargaining with single employers, plant-based works councils also seem to play a role in that they dampen the sensitivity of wages with respect to regional unemployment. The observation that both trade unions and works councils have an influence in wage setting may be interpreted as an indication of the relevance of the bargaining theory explanation of the wage curve, since in this regime there is only limited space for efficiency wages. However, it cannot be ruled out that the higher wages pushed through in these plants also coincide with efficiency wage considerations of employers.

The fact that we did not find a wage curve for plants that apply sectoral agreements reflects institutional rigidities of the German system of wage setting. Since these agreements usually do not to take into account regional or plant-specific factors, it is not very surprising that there is no wage curve visible. What is surprising, however, is the non-existence of a wage curve in the large sub-sample of plants that are not bound by collective agreements since wage adjustments to changing (regional) economic conditions and unemployment should be easiest in the individual wage contracts signed in this group of plants. This finding questions the relevance of efficiency wage considerations. One explanation could be that many plants in this group voluntarily take sectoral agreements as a point of orientation (see Kohaut and Schnabel 2003), so that in order to save transaction costs or maintain social peace in the plant they do not make use of their high legal flexibility in setting wages. Another reason could be that our period of observation is too short to identify 'flat' wage curves. In Germany the correlation of regional unemployment 
rates in the time dimension is high. Therefore, regional fixed effects, which are required to control for regional heterogeneity, might wipe out weak effects of regional unemployment.

While our results refer to a country with moderately high unemployment rates (and may be different in other situations), we have demonstrated that it is important and fruitful to take institutional variables into account when estimating wage curves. Industrial relations and bargaining regimes do not only play a role in wage setting in general but may also influence specifically the relationship between regional unemployment and the wage level. It would be interesting to see whether our results can be replicated for other countries that also show a variety of bargaining regimes or whether a meta analysis of wage curve studies across countries with different dominating bargaining regimes yields additional insights.

\section{REFERENCES}

Addison, John T., Bellmann, Lutz, Schnabel, Claus and Wagner, Joachim (2003): German Works Councils Old and New: Incidence, Coverage and Determinants, Schmollers Jahrbuch (Journal of Applied Social Science Studies) 123, 339-358.

Addison, John T., Schnabel, Claus and Wagner, Joachim (2001): Works councils in Germany: their effects on establishment performance, Oxford Economic Papers 53, 659-694.

Akerlof, George A. (1982): Labor Contracts as Partial Gift Exchange, Quarterly Journal of Economics 97, 543-569.

Alda, Holger, Bender, Stefan and Gartner, Hermann (2005): "The linked employeremployee created from the IAB establishment panel and the process-produced data of the IAB (LIAB)", Schmollers Jahrbuch (Journal of Applied Social Science Studies) $125,327-336$.

Baltagi, Badi H., Blien, Uwe and Wolf, Katja (2009): "New evidence on the dynamic wage curve for Western Germany: 1980-2004", Labour Economics 16, 47-51.

Blanchflower, David G. and Oswald, Andrew J. (1994): The Wage Curve, Cambridge (Mass.), London: MIT Press.

Blanchflower, David G. and Oswald, Andrew J. (2005): The Wage Curve Reloaded, IZA Discussion Paper No. 1665, Bonn. 
Blanchflower, David G. and Oswald, Andrew J. (1996): Efficiency wages and the German wage curve, published in translation: Effizienzentlohnung und die deutsche Lohnkurve, Mitteilungen aus der Arbeitsmarkt- und Berufsforschung 29, 460-466.

Blanchflower, David G., Oswald, Andrew J. and Sanfey, Peter (1996): Wages, profits, and rent-sharing, Quarterly Journal of Economics 111, 227-251.

Büttner, Thiess (1999): The effect of unemployment, aggregate wages, and spatial contiguity on local wages: An investigation with German district level data, Papers in Regional Science 78(1), 47-67.

Carlin, Wendy and Soskice, David (2006): Macroeconomics. Imperfections, Institutions and Policies, Oxford: Oxford University Press.

Elhorst, J. Paul, Blien, Uwe and Wolf, Katja (2007): New Evidence on the Wage Curve: A Spatial Panel Approach, International Regional Science Review 30, 173191.

Fehr, Ernst, Kirchsteiger, Georg and Riedl, Arno (1998): Gift exchange and reciprocity in competitive experimental markets, European Economic Review 42, 134.

Hübler, Olaf and Jirjahn, Uwe (2003): Works Councils and Collective Bargaining in Germany: The Impact on Productivity and Wages, Scottish Journal of Political Economy 50, 471-491.

Jirjahn, Uwe (2009): The Introduction of Works Councils in German Establishments - Rent Seeking or Rent Protection?, British Journal of Industrial Relations 43, 521545.

Keller, Berndt (2004): Employment relations in Germany, in: Bamber, G.J./Lansbury, R.D./Wailes, N. (eds.), International and comparative employment relations. A study of industrialized market economies, 4th ed., Sydney-Singapore, 211-253.

Kohaut, Susanne and Schnabel, Claus (2003): Tarifverträge - nein danke!?, Jahrbücher für Nationalökonomie und Statistik (Journal of Economics and Statistics) 223, 312-331.

Layard, Richard Nickell, Stephen and Jackman, Richard (1991): Unemployment. Macroeconomic Performance and the Labour Market, Oxford: Oxford University Press (new and expanded edition 2005). 
Schank, Thorsten, Schnabel, Claus and Wagner, Joachim (2007): Do exporters really pay higher wages? First evidence from German linked employer-employee data, Journal of International Economics 72, 52-72.

Schnabel, Claus, Zagelmeyer, Stefan and Kohaut, Susanne (2006): Collective Bargaining Structure and its Determinants: An Empirical Analysis with British and German Establishment Data, European Journal of Industrial Relations 12, 165-188.

Shapiro, Carl and Stiglitz, Joseph E. (1984): Equilibrium unemployment as a worker discipline device, American Economic Review 74, 433-444.

Wagner, Joachim (1994): German wage curves, 1979-1990, Economics Letters 44, 307-311. 
Table 1: Distribution of plants and workers according to bargaining regime, western Germany, 2006 (in percent)

\begin{tabular}{|l|c|l|l|c|}
\hline Bargaining regime & \multicolumn{2}{|c|}{ Plants with a collective agreement } & Plants with \\
& $\begin{array}{l}\text { at sectoral } \\
\text { level; } \\
\text { actual wages } \\
\text { not above } \\
\text { agreed scale }\end{array}$ & $\begin{array}{l}\text { at sectoral } \\
\text { level; } \\
\text { actual wages } \\
\text { above agreed } \\
\text { scale }\end{array}$ & $\begin{array}{l}\text { at firm } \\
\text { level }\end{array}$ & \\
\hline $\begin{array}{l}\text { Presence } \\
\text { (Share of plants covered) }\end{array}$ & 22.9 & 20.3 & 3.2 & 53.6 \\
\hline $\begin{array}{l}\text { Bargaining coverage } \\
\text { (Share of workers covered) }\end{array}$ & 26.8 & 29.5 & 8.5 & 35.2 \\
\hline $\begin{array}{l}\text { Presence of a works council } \\
\text { in each group (share of } \\
\text { plants with a works council) }\end{array}$ & 19.5 & 14.0 & 43.9 & 4.4 \\
\hline
\end{tabular}

Notes: Figures are weighted values. Only private-sector plants with at least five employees. First number in last row, for example, implies that 19.5 percent of those plants which are covered by a sectoral agreement and where actual wages are equal to the agreed wage do have a works council.

Source: LIAB, own calculations. 
Table 2: Individual level wage regressions; regional fixed effects; western Germany, 1998-2006

(Dependent variable: logarithm of daily wage)

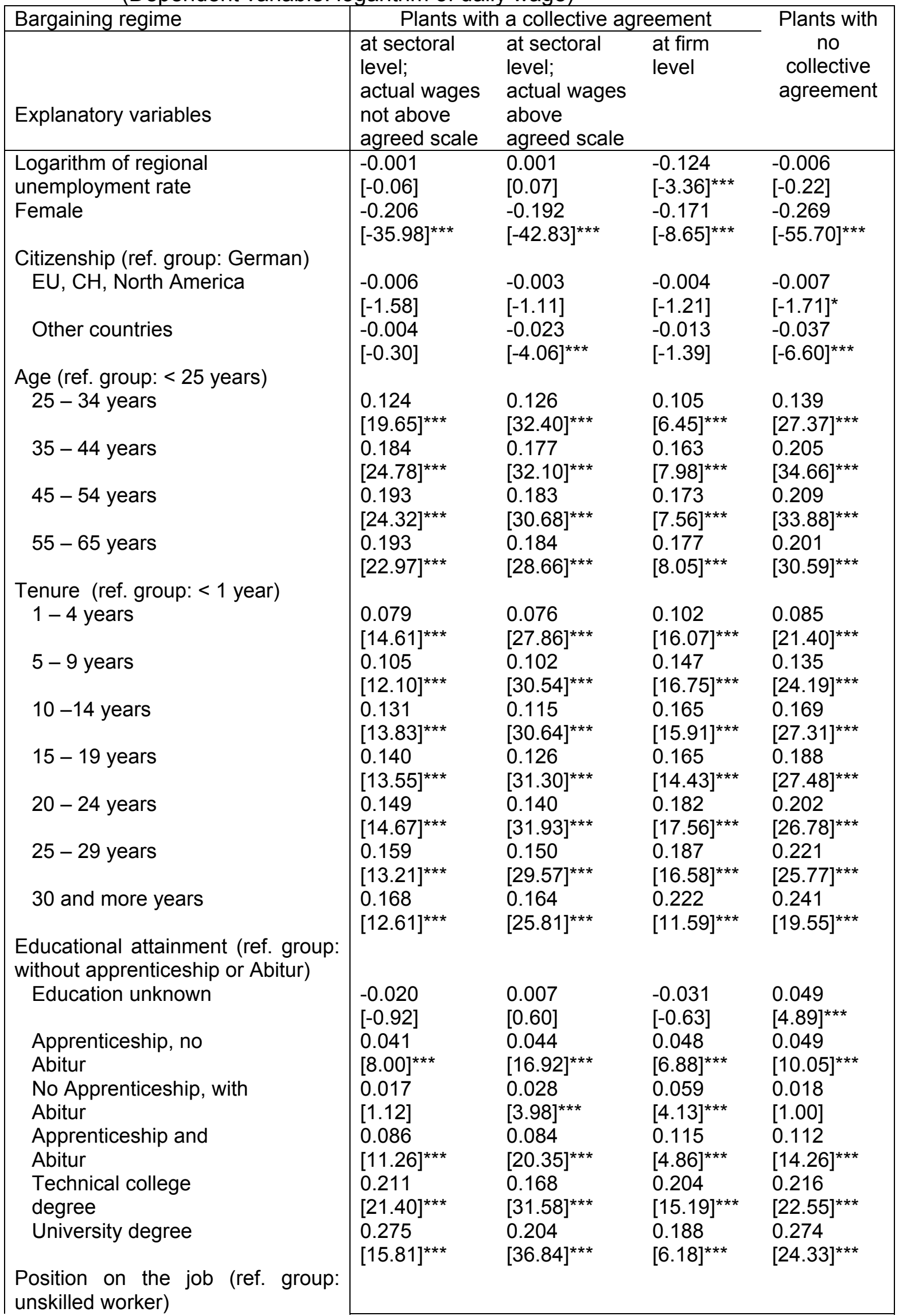




\begin{tabular}{|c|c|c|c|c|}
\hline Skilled worker & $\begin{array}{l}0.075 \\
{[9.91]^{* * *}}\end{array}$ & $\begin{array}{l}0.074 \\
{[15.69]^{* * *}}\end{array}$ & $\begin{array}{l}0.080 \\
{[8.88]^{* * *}}\end{array}$ & $\begin{array}{l}0.116 \\
{[1582]^{* * *}}\end{array}$ \\
\hline Master craftsman, & 0.319 & 0.341 & 0.297 & 0.385 \\
\hline foreman & {$[12.95]^{* * *}$} & {$[53.04]^{* * *}$} & {$[29.71]^{\star * *}$} & {$[48.51]^{* * *}$} \\
\hline Salaried employee & $\begin{array}{l}0.282 \\
{[18.79]^{\star * *}}\end{array}$ & $\begin{array}{l}0.301 \\
{[67.06]^{* * *}}\end{array}$ & $\begin{array}{l}0.269 \\
{[28.56]^{* * *}}\end{array}$ & $\begin{array}{l}0.342 \\
{[51.33]^{* * *}}\end{array}$ \\
\hline \multicolumn{5}{|l|}{$\begin{array}{l}\text { Plant size (ref. group: } 1 \text { - } 9 \\
\text { employees) }\end{array}$} \\
\hline $10-19$ & $\begin{array}{l}0.071 \\
{[5.16]^{* * *}}\end{array}$ & $\begin{array}{l}0.066 \\
{[5.42]^{* * *}}\end{array}$ & $\begin{array}{l}0.004 \\
{[0.10]}\end{array}$ & $\begin{array}{l}0.078 \\
{[7.49]^{* * *}}\end{array}$ \\
\hline $20-49$ & $\begin{array}{l}0.140 \\
{[10.12]^{\star \star \star}}\end{array}$ & $\begin{array}{l}0.118 \\
{[9.95]^{\star \star \star}}\end{array}$ & $\begin{array}{l}0.041 \\
{[1.14]}\end{array}$ & $\begin{array}{l}0.140 \\
{[13.47]^{* * *}}\end{array}$ \\
\hline $50-99$ & $\begin{array}{l}0.138 \\
{[9.16]^{* * *}}\end{array}$ & $\begin{array}{l}0.148 \\
{[11.29]^{\star * *}}\end{array}$ & $\begin{array}{l}0.056 \\
{[1.56]}\end{array}$ & $\begin{array}{l}0.150 \\
{[13.49]^{* * *}}\end{array}$ \\
\hline $100-199$ & $\begin{array}{l}0.160 \\
{[10.38]^{* * *}}\end{array}$ & $\begin{array}{l}0.177 \\
{[13.33]^{\star * *}}\end{array}$ & $\begin{array}{l}0.075 \\
{[2.03]^{* *}}\end{array}$ & $\begin{array}{l}0.159 \\
{[13.18]^{* * *}}\end{array}$ \\
\hline $200-499$ & $\begin{array}{l}0.183 \\
{[11.80]^{\star \star *}}\end{array}$ & $\begin{array}{l}0.200 \\
{[14.99]^{\star * \star}}\end{array}$ & $\begin{array}{l}0.112 \\
{[2.98]^{* * *}}\end{array}$ & $\begin{array}{l}0.169 \\
{[11.94]^{* * *}}\end{array}$ \\
\hline $500-999$ & $\begin{array}{l}0.192 \\
{[11.64]^{* *}}\end{array}$ & $\begin{array}{l}0.219 \\
{[15.88]^{\star * *}}\end{array}$ & $\begin{array}{l}0.161 \\
{[4.08]^{\star * *}}\end{array}$ & $\begin{array}{l}0.218 \\
{[13.70]^{* * *}}\end{array}$ \\
\hline $1000-4999$ & $\begin{array}{l}0.211 \\
{[12.69]^{\star * *}}\end{array}$ & $\begin{array}{l}0.237 \\
{[16.26]^{* * *}}\end{array}$ & $\begin{array}{l}0.117 \\
{[2.72]^{\star * *}}\end{array}$ & $\begin{array}{l}0.252 \\
{[13.21]^{\star * *}}\end{array}$ \\
\hline 5000 and more & $\begin{array}{l}0.167 \\
{[7.28]^{* * *}}\end{array}$ & $\begin{array}{l}0.272 \\
{[17.24]^{* * *}}\end{array}$ & $\begin{array}{l}0.201 \\
{[4.27]^{\star * *}}\end{array}$ & $\begin{array}{l}\text { (no } \\
\text { observations) }\end{array}$ \\
\hline Works council & $\begin{array}{l}0.103 \\
{[9.16]^{\star * *}}\end{array}$ & $\begin{array}{l}0.064 \\
{[7.52]^{\star \star *}}\end{array}$ & $\begin{array}{l}0.060 \\
{[2.55]^{* *}}\end{array}$ & $\begin{array}{l}0.048 \\
{[5.67]^{\star * *}}\end{array}$ \\
\hline \multicolumn{5}{|l|}{ Profitability (ref. group: bad) } \\
\hline Weak & $\begin{array}{l}0.000 \\
{[-0.07]}\end{array}$ & $\begin{array}{l}0.003 \\
{[0.62]}\end{array}$ & $\begin{array}{l}0.007 \\
{[0.56]}\end{array}$ & $\begin{array}{l}-0.003 \\
{[-0.31]}\end{array}$ \\
\hline Standard & $\begin{array}{l}0.020 \\
{[3.37]^{* * *}}\end{array}$ & $\begin{array}{l}0.009 \\
{[1.92]^{*}}\end{array}$ & $\begin{array}{l}0.001 \\
{[0.09]}\end{array}$ & $\begin{array}{l}0.018 \\
{[2.12]^{* *}}\end{array}$ \\
\hline Good & $\begin{array}{l}0.013 \\
{[1.87]^{*}}\end{array}$ & $\begin{array}{l}0.021 \\
{[4.07]^{* * *}}\end{array}$ & $\begin{array}{l}0.015 \\
{[1.51]}\end{array}$ & $\begin{array}{l}0.042 \\
{[4.83]^{* * *}}\end{array}$ \\
\hline Very good & $\begin{array}{l}0.020 \\
{[1.42]}\end{array}$ & $\begin{array}{l}0.030 \\
{[4.91]^{\star * *}}\end{array}$ & $\begin{array}{l}0.015 \\
{[1.29]}\end{array}$ & $\begin{array}{l}0.054 \\
{[4.67]^{\star * *}}\end{array}$ \\
\hline \multicolumn{5}{|c|}{$\begin{array}{l}\text { Production technology (ref. group: } \\
\text { bad) }\end{array}$} \\
\hline Weak & $\begin{array}{l}0.015 \\
{[0.62]}\end{array}$ & $\begin{array}{l}0.016 \\
{[0.82]}\end{array}$ & $\begin{array}{l}0.111 \\
{[3.21]^{* * *}}\end{array}$ & $\begin{array}{l}0.071 \\
{[1.45]}\end{array}$ \\
\hline Standard & $\begin{array}{l}0.046 \\
{[2.17]^{\star *}}\end{array}$ & $\begin{array}{l}0.029 \\
{[1.93]^{*}}\end{array}$ & $\begin{array}{l}0.113 \\
{[3.22]^{\star * *}}\end{array}$ & $\begin{array}{l}0.071 \\
{[1.47]}\end{array}$ \\
\hline Good & $\begin{array}{l}0.056 \\
{[2.64]^{\star * *}}\end{array}$ & $\begin{array}{l}0.036 \\
{[2.52]^{* *}}\end{array}$ & $\begin{array}{l}0.136 \\
{[3.70]^{* * *}}\end{array}$ & $\begin{array}{l}0.084 \\
{[1.73]^{*}}\end{array}$ \\
\hline Very good & $\begin{array}{l}0.054 \\
{[2.50]^{\star *}}\end{array}$ & $\begin{array}{l}0.037 \\
{[2.62]^{\star * *}}\end{array}$ & $\begin{array}{l}0.124 \\
{[3.33]^{* * *}}\end{array}$ & $\begin{array}{l}0.098 \\
{[2.03]^{\star *}}\end{array}$ \\
\hline Plant belongs to a larger unit & $\begin{array}{l}0.014 \\
{[2.20]^{\star *}}\end{array}$ & $\begin{array}{l}0.000 \\
{[0.05]}\end{array}$ & $\begin{array}{l}0.002 \\
{[0.10]}\end{array}$ & $\begin{array}{l}0.025 \\
{[3.61]^{\star * *}}\end{array}$ \\
\hline Constant & $\begin{array}{l}3.609 \\
{[49.76]^{\star * *}}\end{array}$ & $\begin{array}{l}3.733 \\
{[57.92]^{\star * *}}\end{array}$ & $\begin{array}{l}3.999 \\
{[28.56]^{\star * *}}\end{array}$ & $\begin{array}{l}3.470 \\
{[33.19]^{\star * *}}\end{array}$ \\
\hline Observations & $1,177,948$ & $4,207,545$ & $1,021,384$ & 719,400 \\
\hline Employees & 571,278 & $1,521,895$ & 377,772 & 351,535 \\
\hline Plants & 3,382 & 5,456 & 1,255 & 5,517 \\
\hline $\mathrm{R}^{2}$ & 0.62 & 0.65 & 0.64 & 0.63 \\
\hline
\end{tabular}

Notes: Except for the regional unemployment rate, all covariates are dummy variables. Regressions also include dummies for 28 sectors, 325 regions and 8 years. |t|-statistics in parentheses, based on

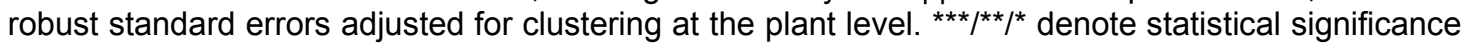
at the $1 / 5 / 10$ percent level, respectively. 
Table 3: Individual level wage regressions; fixed effects; western Germany, 1998-2006 (Dependent variable: logarithm of daily wage)

\begin{tabular}{|c|c|c|c|c|}
\hline \multirow[t]{2}{*}{ Bargaining regime } & \multicolumn{3}{|c|}{ Plants with a collective agreement } & \multirow{2}{*}{$\begin{array}{c}\text { Plants with } \\
\text { no collective } \\
\text { agreement }\end{array}$} \\
\hline & $\begin{array}{l}\text { at sectoral } \\
\text { level; } \\
\text { actual wages } \\
\text { not above } \\
\text { agreed scale }\end{array}$ & $\begin{array}{l}\text { at sectoral } \\
\text { level; } \\
\text { actual wages } \\
\text { above agreed } \\
\text { scale }\end{array}$ & at firm level & \\
\hline Individual Fixed Effects & & & & \\
\hline $\begin{array}{l}\text { Logarithm of regional } \\
\text { unemployment rate }\end{array}$ & $\begin{array}{l}-0.024 \\
{[0.91]}\end{array}$ & $\begin{array}{l}-0.011 \\
{[0.76]}\end{array}$ & $\begin{array}{l}-0.109 \\
{[2.25]^{* *}}\end{array}$ & $\begin{array}{l}0.002 \\
{[0.08]}\end{array}$ \\
\hline $\mathrm{R}^{2}$ & 0.97 & 0.97 & 0.96 & 0.98 \\
\hline Plant Fixed Effects & & & & \\
\hline $\begin{array}{l}\text { Logarithm of regional } \\
\text { unemployment rate }\end{array}$ & $\begin{array}{l}-0.009 \\
{[0.48]}\end{array}$ & $\begin{array}{l}-0.004 \\
{[0.38]}\end{array}$ & $\begin{array}{l}-0.102 \\
{[2.41]^{\star *}}\end{array}$ & $\begin{array}{l}0.000 \\
{[0.02]}\end{array}$ \\
\hline $\mathrm{R}^{2}$ & 0.68 & 0.71 & 0.69 & 0.72 \\
\hline Observations & $1,177,948$ & $4,207,545$ & $1,021,384$ & 719,400 \\
\hline Employees & 571,278 & $1,521,895$ & 377,772 & 351,535 \\
\hline Plants & 3,382 & 5,456 & 1,255 & 5,517 \\
\hline
\end{tabular}

Notes: Regressions include the same covariates as those listed in Table 2. |t|-statistics in parentheses, based on robust standard errors adjusted for clustering at the plant level. ${ }^{* * * / * *} /{ }^{*}$ denote statistical significance at the 1/5/10 percent level, respectively. 
Table 4: Individual level wage regressions; OLS; western Germany, 1998-2006 (Dependent variable: logarithm of daily wage)

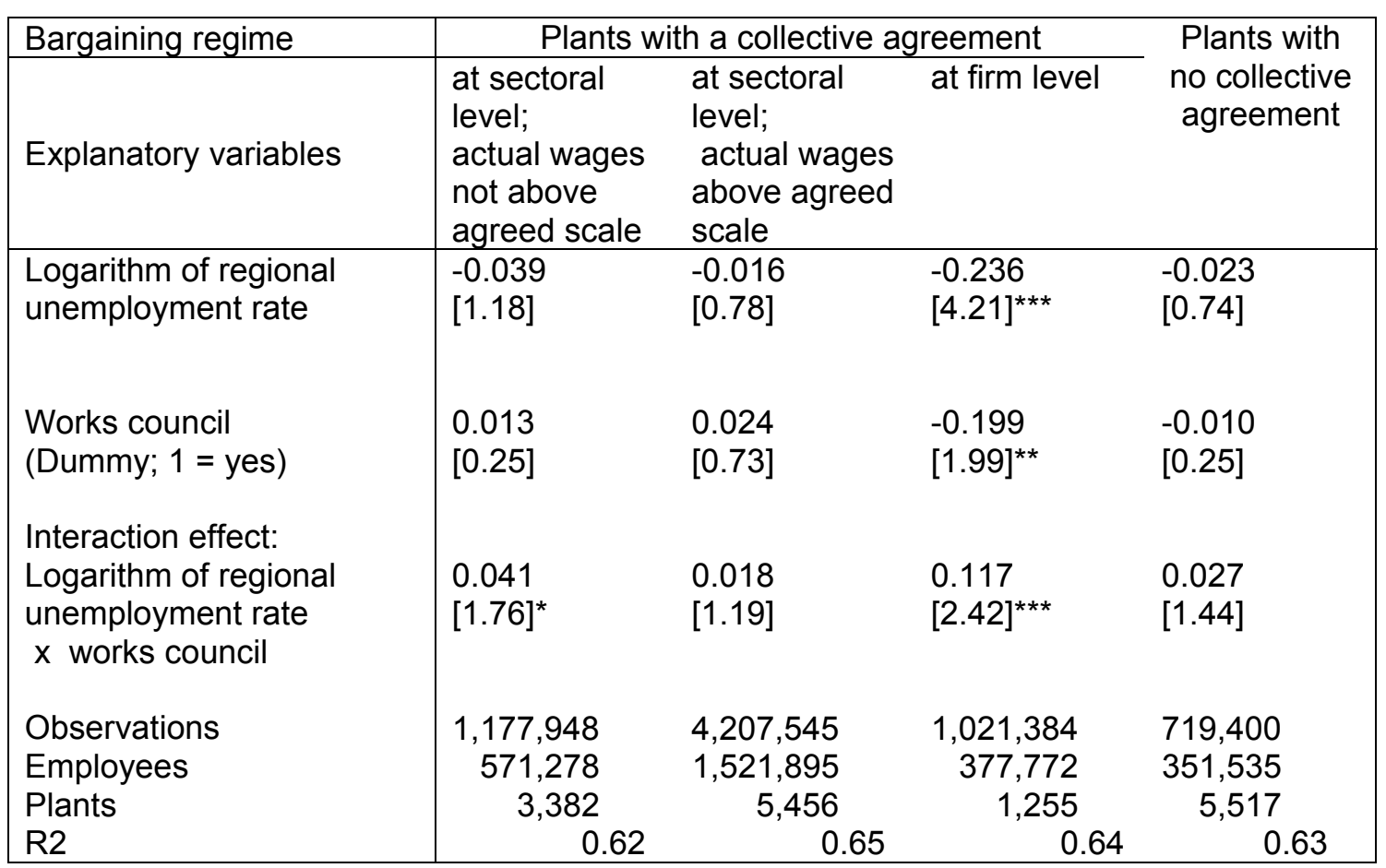

Notes: Regressions include the same covariates as those listed in Table 2. |t|-statistics in parentheses, based on robust standard errors adjusted for clustering at the plant-level. ${ }^{* * *} /{ }^{* *} / *$ denote statistical significance at the 1/5/10 percent level, respectively. 
APPENDIX

Summary statistics of variables used in regression analyses, 1998-2006

\begin{tabular}{|c|c|c|}
\hline Variables & Mean value & Standard deviation \\
\hline $\begin{array}{l}\text { Plants with a collective agreement at sectoral } \\
\text { level, actual wages not above agreed scale }\end{array}$ & 0.165 & 0.371 \\
\hline $\begin{array}{l}\text { Plants with a collective agreement at sectoral } \\
\text { level, actual wages above agreed scale }\end{array}$ & 0.590 & 0.492 \\
\hline Plants with a collective agreement at firm level & 0.143 & 0.350 \\
\hline Plants with no collective agreement & 0.101 & 0.301 \\
\hline Daily wage (in €) & 110.641 & 32.61 \\
\hline Regional unemployment rate (in percent) & 9.850 & 3.30 \\
\hline Logarithm of daily wage & 4.660 & 0.32 \\
\hline Logarithm of regional unemployment rate & 2.228 & 0.35 \\
\hline Female (Dummy, 1=yes) & 0.196 & 0.40 \\
\hline \multicolumn{3}{|l|}{ Citizenship (ref. group: German) } \\
\hline $\mathrm{EU}, \mathrm{CH}$, North America & 0.055 & 0.23 \\
\hline Other countries & 0.050 & 0.22 \\
\hline \multicolumn{3}{|l|}{ Age (ref. group: $<25$ years) } \\
\hline $25-34$ years & 0.233 & 0.42 \\
\hline $35-44$ years & 0.353 & 0.48 \\
\hline $45-54$ years & 0.268 & 0.44 \\
\hline $55-65$ years & 0.097 & 0.30 \\
\hline \multicolumn{3}{|l|}{ Tenure (ref. group: < 1 year) } \\
\hline $1-4$ years & 0.240 & 0.43 \\
\hline $5-9$ years & 0.217 & 0.41 \\
\hline $10-14$ years & 0.164 & 0.37 \\
\hline $15-19$ years & 0.119 & 0.32 \\
\hline $20-24$ years & 0.110 & 0.31 \\
\hline $25-29$ years & 0.077 & 0.27 \\
\hline 30 and more years & 0.011 & 0.10 \\
\hline \multicolumn{3}{|l|}{$\begin{array}{l}\text { Educational attainment (ref. group: without } \\
\text { apprenticeship or Abitur) }\end{array}$} \\
\hline Education unknown & 0.042 & 0.20 \\
\hline
\end{tabular}




\begin{tabular}{|c|c|c|}
\hline Apprenticeship, no Abitur & 0.632 & 0.48 \\
\hline No Apprenticeship, with Abitur & 0.009 & 0.09 \\
\hline Apprenticeship and Abitur & 0.043 & 0.20 \\
\hline Technical college degree & 0.051 & 0.22 \\
\hline University degree & 0.060 & 0.24 \\
\hline \multicolumn{3}{|l|}{$\begin{array}{l}\text { Position on the job (ref. group: unskilled } \\
\text { worker) }\end{array}$} \\
\hline Skilled worker & 0.262 & 0.44 \\
\hline Master craftsman, foreman & 0.021 & 0.14 \\
\hline Salaried employee & 0.405 & 0.49 \\
\hline \multicolumn{3}{|l|}{ Plant size (ref. group: 1 - 9 employees) } \\
\hline $10-19$ & 0.007 & 0.08 \\
\hline $20-49$ & 0.024 & 0.15 \\
\hline $50-99$ & 0.034 & 0.18 \\
\hline $100-199$ & 0.060 & 0.24 \\
\hline $200-499$ & 0.150 & 0.36 \\
\hline $500-999$ & 0.149 & 0.36 \\
\hline $1000-4999$ & 0.362 & 0.48 \\
\hline 5000 and more & 0.212 & 0.41 \\
\hline Works council (Dummy: 1=yes) & 0.917 & 0.28 \\
\hline \multicolumn{3}{|l|}{ Profitability (ref. group: bad) } \\
\hline Weak & 0.162 & 0.37 \\
\hline Standard & 0.315 & 0.46 \\
\hline Good & 0.332 & 0.47 \\
\hline Very good & 0.088 & 0.28 \\
\hline \multicolumn{3}{|l|}{ Production technology (ref. group: bad) } \\
\hline Weak & 0.013 & 0.11 \\
\hline Standard & 0.213 & 0.41 \\
\hline Good & 0.521 & 0.50 \\
\hline Very good & 0.251 & 0.43 \\
\hline Plant belongs to a larger unit (Dummy: $1=y e s)$ & 0.680 & 0.47 \\
\hline
\end{tabular}

